\title{
Effect of ingratiation on supervisor satisfaction through helping behavior: A moderated mediation model
}

\author{
Muhammad Ali Asadullah (D) ${ }^{1}$, Sajid Haider (iD)², Carmen De Pablos Heredero(D², \\ Mariam Musaddiq (iD) ${ }^{1}$ \\ ${ }^{1}$ Air University Multan Campus (Pakistan) \\ ${ }^{2}$ Department of Management Sciences, COMSATS Institute of Information Technology, Vehari Campus (Pakistan) \\ ${ }^{3}$ Universidad Rey Juan Carlos (Spain)
}

maa@aumc.edu.pk,_sajidhaider@,ciitvehari.edu.pk,_carmen.depablos@urjc.es, mariam musaddiq@yahoo.com

Received February, 2016

Accepted August, 2016

\section{Abstract}

Purpose: This research intends to investigate the mediating role of helping behavior in relationship between employee ingratiation and supervisor satisfaction across high and low levels of ingratiation behavior, and answers the questions: how, when and why ingratiation is effective.

Design/methodology: Data were collected through questionnaire surveys in hotel industry, and structural equation modelling was applied to analyze these data by using hypotheticaldeductive approach.

Findings: The results indicate that helping behavior is an important mediator of the relationship between ingratiation and supervisor satisfaction. Moreover, ingratiation is also a strong moderator of the relationship between helping behavior and supervisor satisfaction. This research concludes that employee ingratiation positively predicts helping behaviors, and consequently the supervisor satisfaction. 
Research limitations/implications: This study is not experimental in nature, but a crosssectional design has been followed. Future research can focus on an experimental design by incorporating a time element, and the design and analysis should be nested since this study did not use multilevel analysis. Moreover, this study used only two forms of ingratiation for measuring employee ingratiation behavior. We suggest researchers to consider all four dimensions of ingratiation by using some distinct scales.

Practical implications: This research explains mechanisms underlying supervisor-subordinate relationship, and contributes to organizational behavior research by answering the question; 'when and how ingratiation could be effective?' The findings of this study have important managerial implications, and provide future lines of research.

Social implications: The findings of this research demonstrate that ingratiation is an important tool for satisfying superiors if employees exhibit helping behaviors towards coworkers and supervisors. Particularly, new employees can benefit from ingratiation to socialize within work organizations. Moreover, existing employees can use ingratiation to establish as well as maintain better social relations with supervisors and colleagues.

Originality/value: Previous research emphasized more on customer-directed employee ingratiation but this study offers its contribution by emphasizing coworker as well as supervisor directed employee ingratiation. Moreover, this study measures effectiveness of ingratiation in terms of employee task performance representing supervisor satisfaction.

Keywords: Ingratiation, Helping Behavior, Supervisor Satisfaction, Mediation, Moderation

Jel Codes: M1, L1

\section{Introduction}

Research on supervisor-employee relationship has widely discussed employee's satisfaction with his or her supervisor (Jernigan \& Beggs, 2005). Unfortunately, supervisor's satisfaction with his or her employee has received a relatively less attention (Rich, 2008). Supervisor's satisfaction with employee refers to supervisor's perception of how well an employee performs his or her job, and what image he or she has in doing that job (Rich, 2008). The literature on supervisor's satisfaction with employee 
performance seems to focus on employee's personality and ability to perform a specific job (Kolo, 2006). In this regard, social interaction processes have been relatively less explored (Hackman, 1986; Liden \& Mitchell, 1988). Hence, there is need to work on social interaction processes to understand how, other than personality and ability, employees make efforts to achieve supervisor satisfaction.

As careers are evolving expeditiously, the importance of self management and social interactions is increasing among employees (Arthur \& Rousseau, 1996; Wu, Kwan, Wei \& Liu, 2013). In addition to career growth, the need for effective impression management (Harris, Kacmar, Zivnuska \& Shaw, 2007) resulting from high work pressures also increases the importance of social interactions targeted at supervisors. In many service organizations employees closely interact with their supervisors. Usually, these employees remain under high pressure of their supervisors' demands for exhibiting high professional attitudes towards customers. Moreover, heavy workloads make them victims of workfamily and family-work conflicts (Choi \& Kim, 2012; Davidson, Timo \& Wang, 2010; Deery, 2008). Consequently, they experience high emotional labor, become highly demotivated and dissatisfied, develop high turnover intentions and their job performance reduces. Lost in these problems, they are more likely to involve themselves in supervisor-focused social influence tactics for developing and maintaining their impression in front of their supervisors (Ma \& Qu, 2011).

Insights from Goffman's (1959) theory of impression management suggest that people engage in self presentation to control others' reactions to them (Leary \& Kowalski, 1990, pp. 37). As an impression management tactic, ingratiation is a deliberate effort of an employee to display those behaviors which are usually preferred by his or her supervisor or organization (Appelbaum \& Hughes, 1998). Ingratiation refers to "those episodes of social behavior that are designed to increase the attractiveness of the actor to the target" (Jones, 1964, pp. 2). It enables people to acquire social influence on behalf of social relations (Jones, 1964). Ingratiation directed upwards in organizational hierarchy usually targets supervisors (Porter, Allen \& Angle, 1981; Ralston, 1985). Supervisor-attributed motivation theory explains that employees ingratiate their supervisors either to maintain and manage their impression, or to satisfy prosocial motives (Ashford \& Cummings, 1983; Ashford \& Tsui, 1991; Grant, 2008; Lam, Huang \& Snape, 2007). However, little empirical evidence exists on the relationship between employee ingratiation and supervisor satisfaction.

Moreover, a review of existing literature suggests that the researchers have reported both positive and negative consequences of employee ingratiation. Scientists of positive psychology, however, remained more interested in positive consequences. For example, Judge and Bretz (1994) illustrated that ingratiation facilitates an employee to build image in front of his or her supervisor. Treadway, Ferris, 
Duke, Adams and Thatcher (2007) reported that ingratiation facilitates employees in achieving personal as well as career goals. However, they found that supervisors rated lower those subordinated who were highly engaged in ingratiation behavior. Empirical evidence suggests that ingratiation does not always result in positive consequences. For instance, Park, Westphal and Stern (2011) investigated how ingratiation increases overconfidence of a CEO leading him towards biased strategic decision making. Ingratiation can lead employees to distress, particularly, if the employee is lacking political skills (Wu, Yim, Kwan \& Zhang, 2012). This swing of pendulum between positive and negative poles of ingratiation outcomes requires researchers to understand mechanisms underlying the relationship between employee ingratiation and supervisor satisfaction (Beehr et al., 2006). Examining such mechanisms can strengthen this line of research. However, less attention has been paid to identify and examine the factors explaining this relationship.

Given the above mentioned gaps in existing research, this study, using insights from Theory of Impression Management (Goffman, 1959), Theory of Reasoned Action (Fishbein \& Ajzen, 1975), Expectancy Theory (Vroom, 1964) and other relevant theories, extends ingratiation and supervisor satisfaction research by empirically examining the relationship between employee ingratiation behavior and supervisor satisfaction. Moreover, this research intends to investigate the mediating role of helping behavior in this relationship across high and low ingratiation behavior, and answers the question; how, when and why supervisor-focused ingratiation is effective. Helping or extra-role behavior refers to a discretionary and positive behavior that goes beyond an employee's formal job descriptions (Organ, 1988). For the purpose of this research helping behavior means employee's helping behavior toward coworkers and supervisor. Helping behavior can possibly mediate this relationship due to employee's impression management motives i.e. portraying herself or himself as a good citizen in front of a supervisor (Eastman, 1994; Bolino, Kacmar, Turnley \& Gilstrap, 2008; Bolino, Long \& Turnley, 2016). This study also investigates the moderating role of ingratiation in the relationship between employee helping behavior and supervisor satisfaction. This study extends research on ingratiation behavior by explaining mechnisms through which the relationship between ingratiation and supervisor satisfaction is clarified. The findings of this study have important managerial implications, and provide future lines of research. 


\section{Theoretical Framework and Hypotheses}

\subsection{Employee ingratiation and supervisor satisfaction}

As already discussed, ingratiation is an impression management tactic which refers to the process used by people for controlling others' impression toward them (Goffman, 1959; Leary \& Kowalski, 1990). According to Jones (1964) ingratiation is a "class of strategic behaviors illicitly designed to influence a particular other (...) concerning the attractiveness of one's personal qualities" (1964, pp. 11). From this definition, one can imagine that the major purpose of exhibiting ingratiation is to influence someone. As discussed earlier, evidence from existing literature shows that we can expect both positive and negative consequences of ingratiation. However, the important point is to understand why employees continue ingratiating their supervisors if they face negative consequences also. Ingratiation is neither a disease nor a psychological disorder. It can discourage a normal and healthy ingratiator to exhibit more ingratiation if he or she remains unsuccessful in achieving desired behaviors or receives negative behaviors from superiors. Insights from the Theory of Reasoned Action (Fishbein \& Ajzen, 1975) and Reinforcement Theory (Skinner, 1963, 1971) inform that a person involves in a certain behavior after considering its consequences. Moreover, these theories assume that a person's association with a specific behavior is not only because of internal elements (i.e. personality) but the external factors also influence his or her behavior towards a particular direction. Ralston (1985) argued that ingratiation is not only individually initiated but also organizationally induced phenomenon. In other words, an ingratiator's individual action is not the only source of ingratiation; organizational factors also require her or him to exhibit such behavior. It is quite possible that an employee involves in ingratiation because the supervisory behavior in the organization requires that, or gives positive acceptance to such behavior. If this is the case, it is also possible that supervisors show more satisfaction towards ingratiating employees. Vroom's (1964) Expectancy Theory guides that a person's use of influence tactic happens after the cognitive evaluation of the success or failure resulting from it. People choose to exhibit a behavior or take an action for which their perceptions of success are high, and they expect the results beneficial to them (Steizel \& Rimbau-Gilabert, 2013). Based on this discussion, we expect that employees involve in supervisor-focused ingratiation because it satisfies their supervisors.

Hypothesis 1: Employee's ingratiation behavior is positively associated with supervisor satisfaction. 


\subsection{Employee Ingratiation and Helping Behavior}

Although the relationship between employee ingratiation and supervisor satisfaction can be established based on existing theory and evidence, the mechanisms underlying this relationship are not clear yet. This research introduces employee helping behavior as a factor clarifying the relationship between ingratiation and supervisor satisfaction. In order for a factor to act as a clarifying or mediator variable, independent variable should significantly predict it (Baron \& Kenny, 1986). Therefore, there is a need to develop argument for the association between ingratiation and helping behavior.

Various researchers investigated ingratiation to advance theory and research, but a few of them addressed its effectiveness. Positive psychology guiding individuals to behave more effectively (Gable \& Hadit, 2005; Seligman \& Csikszenmihalyi, 2000) can help in determining effectiveness of ingratiation. The researchers of positive psychology are interested in finding out organizationally favorable employee behaviors like organizational citizenship behavior (OCB), to improve strategic effectiveness of an organization (Ghalamkari, Mahmoodzadeh, Barati, Isah-Chikaji, Alkali \& Anvari, 2015). The studies investigating the relationship between ingratiation and helping behavior are very limited. A mere exception is the work of Eastman (1994) who investigated relationship between ingratiation and OCB, and argued that ingratiation and $\mathrm{OCB}$, which were previously considered distinct from each other, are in fact similar and intertwined. Further, Nguyen, Seers and Hartman (2008) found that ingratiation and OCB are positively associated. Since, helping behavior is also a form of OCB (Bateman \& Organ, 1983; Eastman, 1994) this study assumes positive association of ingratiation and helping behavior.

Three different theories, i.e. Balance Theory (Heider, 1958), Social Exchange Theory (Blau, 1964) and Interdependence Theory (Kelley \& Thibaut, 1978) provide theoretical support for the association between ingratiation and helping behavior. Social exchange theory describes that social exchange is the base of individuals' interpersonal relations (Cook \& Rice, 2003). Social exchanges can be directed towards supervisors, coworkers and customers $(\mathrm{Ma} \& \mathrm{Qu}, 2011)$. Interdependence theory that is part of social exchange theory (Johnson \& Johnson, 2002) suggests that individuals tend to increase their rewards and reduce their costs by maintaining their relationships (Holmes, 2002). Interdependence is a key characteristic of any organizational settings including service organizations where teamwork exists. Together, social exchange theory and interdependence theory describe that social exchange is also directed from one employee to the other and employees may use ingratiation to maintain a relationship with a coworker or supervisor to obtain help in future. Further, the Balance Theory (Heider, 1958) explains that attaining balance is an implied purpose of social connections. Thus, an employee who has received ingratiation from a coworker or supervisor could feel obliged to balance by helping them in a 
similar situation. The principal of reciprocity (Gouldner, 1960; Cialdini, 2001) also supports the notion that people have a greater tendency to like those people who like them. It means that ingratiation from a coworker may lead an employee to like him/her and obviously, any individual is highly likely to help those whom he/she likes more. When all this happens, the supervisors and coworkers observing this phenomenon can make positive attributions of the existence of helping behaviors in their team. Although inconsistent in Eastman's (1994) sense, the illusionary attributions of OCBs for these ingratiation behaviors are likely to create a spillover effect towards real helping behaviors in teams. We agree with Jones \& Wortman (1973) and Gurevitch (1985) that employees identified as ingratiators are considered ineffective, and face negative attitudes from others. Nevertheless, our previous discussion based on the principal of reciprocity and other theories reveals that despite its negative image in the eyes of beholder (Eastman, 1994) ingratiation has ability to create an environment of helping behaviors within teams. Consequently, these helping behaviors can satisfy not only coworkers but also supervisors. Based on previous arguments, this study assumes that employees, using ingratiation as an influence tactics, are highly likely to exhibit helping behavior. Thus, we hypothesize that ingratiation and helping behavior are positively associated with each other.

Hypothesis 2: Employee's ingratiation behavior is positively associated with his/her helping behavior toward coworkers and supervisor.

\subsection{Helping Behavior and Supervisor Satisfaction}

Employee behavior inside an organization is categorized as in-role and extra role behavior (Katz, 1964). In-role behavior is based on routine jobs and is part of employee job description while extra-role behavior, as already described, is discretionary and positive that goes beyond formal job descriptions. Based on the increasing need to differentiate among extra role and in-role behaviors, Van Dyne, Cummings and McLean Parks (1995) developed typology of extra role behaviors and described that extra role behavior are primitive or prohibitive and affiliative or challenging. Promotive behaviors cause or promote a behavior to occur, whereas prohibitive behaviors prevent or stop an employee to experience inappropriate or unethical behavior. Affiliative behaviors are interpersonal and otheroriented which strengthen relationships whereas challenging behaviors are change-oriented and damage relationships.

Helping behaviors are required, especially, in those organizations where most of the work is done in teams, and employee cooperation is required to perform interdependent tasks (Van Dyne \& Le Pine, 
1998). Previous research has also reported various positive effects of helping behavior, particularly on personal development (Hansen, Larson \& Dworkin, 2003) and physical and psychological well-being (Brown, Nesse, Vinokur \& Smith, 2003; Sonnentag \& Grant, 2012; Glomb, Bhave, Miner \& Wall, 2011). Spitzmuller and Van Dyne (2013) distinguished between two streams of research on helping; first stream of research is based on social exchange theory that treats helping behavior as a reactive behavior while the second is based on the functional motives approach that treats helping as a proactive behavior. While differentiating between reactive and proactive helping behavior Spitzmuller and Van Dyne (2013) stated that reactive helping is responding to others needs, whereas proactive helping behavior originates from within the individual for self-serving motives (like reputation, well-being, favorable self-evaluations, need satisfaction, and self-development). Proactive helping encourages an employee to take an initiative in expectation of some future outcomes (Spitzmuller \& Van Dyne, 2013) either to take control or to cause change (Parker \& Collins, 2010). Generally, proactive behaviors are preferred over reactive behaviors (Spitzmuller \& Van Dyne, 2013). Since a supervisor's hierarchical position in organization allows him/her to exercise a considerable level of formal power, helping serves as a proactive behavior for employees to achieve supervisor satisfaction. Although extra-role behaviors are not rewarded like in-role behaviors, supervisors value them (Van Dyne \& LePine, 1998). Helping is highly important as some situations could involve helping as a part of the in-role performance like nursing (Van Dyne \& LePine, 1998) however, helping is an affiliate, promotive, cooperative and noncontroversial extra role behavior that is imperative for building or preserving the relationships (Van Dyne et al., 1995; Van Dyne \& LePine, 1998). The delivery of customer services inside a service organization requires employees to work together and interact regularly, but supervisors treat each employee differently (Kim, O'Neil \& Cho, 2010). Moreover, supervisors owe the power to increase pay, assign jobs and promote employees (Janssen \& Van Yperen, 2004). Since helping facilitate employees in managing impression in front of supervisors (Rioux \& Penner, 2001), employee enjoying close relationship with supervisor, as described by leader-member exchange theory (Liden, Sparrowe \& Wayne, 1997), could enjoy high support in the form of personal and career related benefits (Harris, Kacmar \& Witt, 2005). Employees are likely to make comparison with each other regarding their interpersonal relationships with supervisor and other employees (Kim et al., 2010). Thus, employees could exhibit high levels of helping to enhance their self-image. Some empirical (Yun, Takeuchi \& Liu, 2007) and meta-analytic studies (Podsakoff, Whiting, Podsakoff \& Blume, 2009) supported that employees engage more in extra role behavior to improve their self-impression. This environment of high coworker helping behavior improves quality of service because employees deliver high quality services when they perceive and receive support from their coworkers (Susskind, Kacmar \& Borchgrevink, 2007). It can be expected that supervisor's satisfaction will increase in the presence of 
helping behaviors in his/her team members. Thus, this study hypothesizes that helping behavior is positively associated with supervisor satisfaction.

Hypothesis 3: Employee's helping behavior toward coworkers and supervisor is positively associated with supervisor satisfaction.

\subsection{Mediating Role of Helping Behavior}

Impression management tactic could be verbal or nonverbal (Peters \& Lievens, 2006). Verbal tactics are either assertive or defensive. Assertive verbal tactics are other-focused, and are used to construct selfimage. Liden and Mitchel (1988) demonstrated four reasons for an employee to demonstrate ingratiation: desire to be liked; to maintain a positive image as attractive (Cooper \& Fazio, 1984; Festinger, 1957) and competent; to enhance the self (Epstein, 1973) and to fulfill defensive and assertive needs (Tedeschi \& Melburg, 1984). Ingratiation is an assertive, other- focused, verbal impression management tactic (Peters \& Lievens, 2006) that employees use to satisfy their assertive needs like expected positive reactions of other employee (Tedeschi \& Melburg, 1984) including high supervisor ratings. Thus, supervisor satisfaction acts as an assertive need that drives an employee to ingratiate their supervisors. Supervisor-attributed motive theory distinguished between two different categories of supervisor-attributed motives, i.e. pro-social motives and impression management motives (Ashford \& Cummings 1983; Ashford \& Tsui, 1991; Grant, 2008; Lam et al., 2007). However, supervisors are highly likely to interpret employee's intentions to ingratiate (Thomas \& Pondy 1977) that makes ingratiation risky for employees (Liden \& Mitchell, 1988). Particularly, the employee could be at a greater disadvantage if ingratiation motives are instrumental in nature, like acquiring resources (Ralston, 1985) or to ensure career success (Ferris, Frink, Beehr \& Gilmore, 1995).

Balance Theory describes that balance occurs when the sentiments of supervisor towards employee ingratiation are favorable yet achieving balance is difficult in organizational settings due to hierarchical distribution of power (Treadway et al., 2007). Additionally, supervisor may also interpret ingratiation as an employee's self-serving motive. The increased risk of employee to achieve balance could lead an employee to use some mechanisms to mask self-serving intentions (Bolino \& Turnley, 1999; Ferris et al., 1995). Since extra role behaviors towards other employees and supervisor positively affect supervisors' ratings of employee performance and reward recommendations, employees are more likely to demonstrate these behaviors as a part to strengthen their self-image (Yun et al., 2007). Current study introduces helping behavior as a readily available mechanism for employees to mask their intentions. 
Helping is sub-dimensions of organizational citizenship behavior that is highly appreciated by supervisors (Van Dyne \& LePine, 1998). Helping could be both verbal as well as nonverbal in nature that is either an assertion or a defensive impression management tactic. The classification of helping behavior by Spitzmuller and Van Dyne (2013) as proactive is an assertive impression management tactic whereas reactive form of helping is a defensive impression management tactic. It is important to note that defensive impression management tactics are used to repair one's image therefore helping behavior could serve as a fruitful mechanism for any employee to overcome the risk associated with ingratiation and to balance ingratiation and supervisor reaction relationship. Therefore, helping behavior could easily facilitate employee to bridge ingratiation and supervisor satisfaction relationship.

Based on hypothesis one and two, and discussion about the correlation of ingratiation and helping behavior (Organ, 1988), it can be assumed that helping behavior toward coworkers and supervisor, positively predicts supervisor satisfaction because the ingratiator is forced to exhibit helping behavior to achieve balance due to supervisors' hierarchical position. Therefore, this study hypothesizes that helping behavior mediates the relationship between employee ingratiation and supervisor satisfaction. The general notion is that subordinate ingratiates supervisor to achieve favorable supervisor sentiments, but cannot achieve balance due to the greater formal power of supervisor. Thus, subordinate fills this gap by exhibiting helping behavior. Since helping behavior positively affects quality of work (Susskind et al., 2007) it can be expected that supervisor's satisfaction for that employee will increase. Thus, this study hypothesizes that:

Hypothesis 4: Employee belping behavior toward coworkers and supervisor mediates the relationship between ingratiation behavior and supervisor satisfaction.

\subsection{Moderating Role of Ingratiation Behavior}

Previous research provides mix evidence regarding consequences of helping behavior (Spitzmuller \& Van Dyne, 2013). Some studies show that helping begets positive consequences like well-being (Glomb et al., 2011; Sonnentag \& Grant, 2012), self-evaluations (Van Willigen, 1998), physical and mental health (Brown et al., 2003) and personal development (Hansen et al., 2003). Other studies demonstrate that, in some situations, helping could also bring negative consequences for an actor like lower evaluation of job performance and slower career progression (Bergeron, 2007), stress, overload, work-family conflict (Bolino \& Turnley, 2005), decreased sales performance (Podsakoff \& MacKenzie, 1994) and lower product quality (Podsakoff, Ahearne \& MacKenzie, 1997). 
Owing to conflicting empirical evidences, researchers are still investigating "in what situations or when can 'helping' bring positive consequences for the actor?" Such questions are most often answered through moderation analysis (Hayes, 2012, pp. 2). This study investigates moderating effect of employee ingratiation on the relationship between helping behavior and supervisor satisfaction. Ingratiation is a political skill, and political skills can strongly affect impression management techniques as described by social influence theory (Levy, Blatt \& Shaver, 1998). As a political influence tactic, ingratiation can strongly influence the relationship between helping behavior and supervisor satisfaction. The employee receives a less favorable impression from a supervisor in situations where extra role behaviors are interpreted as impression management motives. However, employee expects positive attribution of ingratiation from supervisor (Castro, Douglas, Hochwarter, Ferris \& Frink, 2003; Johnson, Smith-McLallen, Killeya \& Levin, 2004). Balance Theory (Heider, 1958) and the principle of reciprocity (Jones, 1964) both support that ingratiation makes the target feel great and balance or reciprocate with positive exchanges. For instance, if a subordinate does those things which supervisor likes, the supervisor may uphold positive stance about employee to make a balance. Similarly, if subordinates do those things which supervisor dislikes, the supervisor holds negative attitude towards subordinates (Wu et al., 2013). Thus, ingratiation may moderate the relationship between helping and supervisor satisfaction and employees may achieve higher supervisor ratings even in situations when the supervisor responds less favorably to helping (as extra role behavior). Political skills enable individuals to comprehend other and control the situations (social influence theory (Levy et al., 1998)). Therefore, it is highly likely that individuals who demonstrate high ingratiation behavior are capable of achieving higher supervisor ratings as compared to employees who exhibit low ingratiation behavior. Ferris et al. (2005) found that employees having better political skills can obtain better job performance appraisal. Since ingratiation is also a political influence tactic, employees who use ingratiation in the situation when their helping behavior is not resulting in positive consequences are highly likely to obtain higher performance ratings from their supervisors. Based on these arguments, this study hypothesizes that ingratiation moderates the relationship between helping behavior and supervisor satisfaction.

Hypothesis 5: Ingratiation behavior moderates the relationship between employee helping behavior and supervisor satisfaction such that relationship is stronger when ingratiation is high and relationship is weaker when ingratiation is low. 


\subsection{Moderated Mediation}

The fourth hypothesis of the study stated that helping behavior mediates the relationship between ingratiation and supervisor satisfaction, and the fifth hypothesis assumed the moderating role of ingratiation between helping and supervisor satisfaction. The sequence of these hypotheses signifies moderated mediation that occurs when the mediating effect of a variable depends upon the level of a third variable (Bauer, Preacher \& Gil, 2006; Edwards \& Lambert, 2007). As stated earlier, mediation facilitates researchers in answering questions of 'how' and moderation facilitates them in answering questions of 'when' (Hayes, 2012). Unfortunately, methods for answering 'how' and 'when' questions simultaneously were still lacking which could have led to incomplete explanations of the mechanisms (Hayes, 2012). Introduction of moderated mediation methodology facilitates researchers to answer 'how' and 'why' questions together. The authors benefitted from moderated mediation approach and tested if mediating role of helping between ingratiation and supervisor satisfaction differs across high and low ingratiation behavior.

Ingratiation is an assertive influence tactic that could alter supervisors' perception regarding the employee. The intensity of ingratiation may determine the level of significance of the mediating role of helping behavior between ingratiation and supervisor satisfaction. Particularly, this indirect effect would be insignificant for employees who exhibit low ingratiation and significant for employees who exhibit high ingratiation behavior. Thus, we hypothesized that:

Hypothesis 6a: The mediating role of helping behavior between employee ingratiation and supervisor satisfaction would be significant for employees demonstrating high ingratiation.

Hypothesis 6b: The mediating role of helping behavior between employee ingratiation and supervisor satisfaction would be insignificant for employees demonstrating low ingratiation.

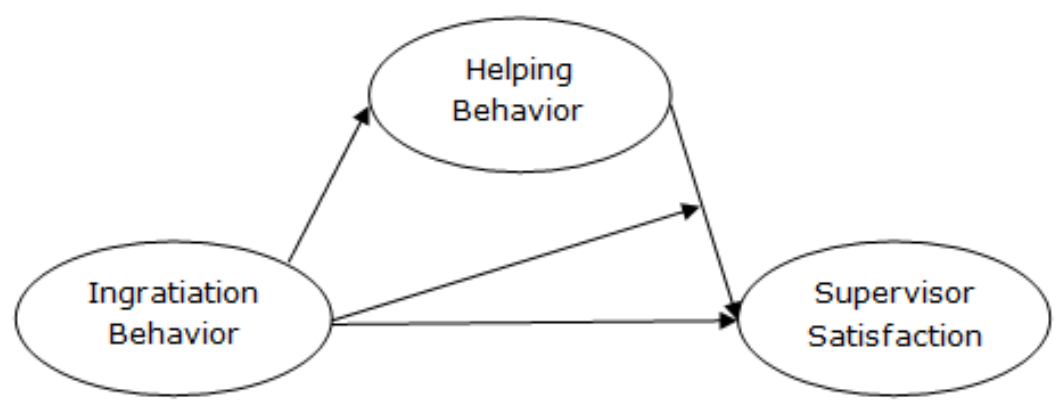

Figure 1. Hypothetical Framework 


\section{Research Methodology}

\subsection{Sample}

Front line employees in service organizations directly interact with customers as well as their supervisors who evaluate their performance in terms of service delivery. Any customer complaint could make an employee's position more vulnerable in front of their supervisors. Such employees could exhibit ingratiation to obtain favorable ratings from supervisors. Thus, participants in this study were front line employees and their supervisors working in the hotel industry of federal capital Islamabad, Pakistan. Islamabad, being the capital city, is synchronized with other cities of the world, and has a modern culture. Overall, the culture of Islamabad is a mix of Islamic, Western, and Indian cultures. The survey took place during September-October 2015. This study used a purposive sampling method to collect data from key informants, i.e. frontline employees and their supervisors, who were able to provide us with relevant information. The ability of participants to understand the objective of this research and provide relevant information makes the sample important. Data were collected from 168 supervisors and 453 subordinates working in 35 hotels (2 to 3 star) located in Islamabad, the capital of Pakistan. The majority of hotels in Islamabad are 2 to 3 star nationally owned hotels. These hotels were focused for data collection due to easy access to supervisors and employees. The major occupants of these hotels are government officials, employees of national and international organizations, and a small number of tourists. The supervisors and employees in these hotels are Pakistani nationals. Five star hotels are small in number, and researchers' access to these hotels involves complex processes, and these hotels were not included for the purpose of simplicity and time saving. Each of the supervisors in selected hotels rated employees' helping behavior and their satisfaction with employees in terms of employee task performance. The supervisor rated at least three employees working under his/her supervision. The subordinates provided their ratings regarding ingratiation. We obtained minimum four cases from each hotel.

\subsection{Procedures}

Data collection began with a pilot study in which data were collected from 30 respondents of two hotels. The reliability estimates for measures of ingratiation behavior and helping behavior were adequate. However, reliability estimates of 'supervisor satisfaction' scale were relatively low (alpha $=.66$ ). The reliability estimates improved significantly (alpha $=.73$ ) after dropping one item from the scale. Front line employees of hotel industry are expected to understand well English language. 
Therefore, the survey was administered in English language. A cover letter with the questionnaires that sought the consent of participants and ensured the privacy of data was attached. First, questionnaires were distributed among supervisors containing items of employee proactive helping behavior and supervisor satisfaction. Supervisors were requested to provide their ratings on helping behavior and performance of employees working under their supervision since, at least, one year. Each supervisor provided ratings about three employees at minimum. A coding scheme to match the responses of supervisors with relevant employees was used. Then corresponding employees were contacted to obtain ratings on ingratiation behavior. We did not disclose employees that we have already obtained information from their supervisors about them. Terms as 'ingratiation' were avoided to remove any kind of perceptual biases and positive terms like 'opinion conformity' were used while explaining them the purpose of study.

\subsection{Measures}

\subsubsection{Employee - Provided Measures}

\subsubsection{Ingratiation Behavior}

Four different dimensions of ingratiation have been reported in literature, which include

- Flattery,

- opinion Conformity,

- $\quad$ self-promotion, and

- favor.

Following Park et al. (2011), we considered only flattery and opinion conformity to measure ingratiation behavior because other two constructs (self-promotion and favor) are different and separate constructs as described in some previous studies e.g. 'the ingratiator wants to be liked: the selfpromoter wants to be seen as competent' (Jones \& Pittman, 1982; Godfrey, Jones \& Lord, 1986, pp. 106). Taking above explanation into account, we remained focused on likeness of ingratiator, and used the nine item scale developed by Kumar and Beyerlein (1991) and Westphal (1998), Westphal and Stern (2007), which was later used by Park et al. (2011). The scale used by Park et al. (2011) was directed at CEOs. This scale was adapted in this analysis with respect to our context. Participants responded on a 
5-point Likert-type scale in which first two items were measured on the scale ranging from $1=$ 'not at all' to $5=$ 'to a very great extent' and the rest of 7 items were measured on a scale ranging from $1=$ 'never' to 5= 'very frequently.' The sample item included 'over the past six months, how often have you complimented the supervisor about his/her insight on a particular work related issue?' The internal consistency reliability of the scale (Cronbach's alpha) was 0.85 .

\subsubsection{Supervisor- Provided Measures}

\subsubsection{Supervisor Satisfaction}

Supervisor's satisfaction was measured using 7-item scale developed by Williams and Anderson (1991). All items were measured on a five point Likert scale ranging from $1=$ not at all to $5=$ extremely. The sample item included 'This employee engages in activities that will directly affect his/her performance appraisal.' The internal consistency reliability of the scale (Cronbach's alpha) was 0.67.

\subsubsection{Helping Behavior}

The supervisors rated helping behavior of their subordinates on a 7-item scale validated by Van Dyne and LePine (1998). Van Dyne and LePine (1998) originally adapted four items of this scale from Organ and Konovsky (1989), and Smith, Organ and Near (1983) and the rest of the three items from Williams and Anderson (1991) scale. The responses of all items were obtained on a 5-point Likert scale ranging from ' $1=$ never' to ' $5=$ very frequently'. The items of this questionnaire are targeted at evaluating employee's helping behavior toward both coworkers and supervisor. The sample items include; 'This employee volunteers to do things for this workgroup', 'This employee assists supervisor with his/ her work (When not asked)' and 'This employee takes time to listen to coworker's problems and worries'. The internal consistency reliability of the scale (Cronbach's alpha) was .90. 


\subsubsection{Control Variables}

According to Treadway et al. (2007), gender and tenure are significant predictors of ingratiation. Similarly, gender could also affect performance ratings (Bowen, Swim \& Jacobs, 2000). Thus, we introduced age, gender, and tenure as control variables. $83 \%$ of the respondents were male and $17 \%$ were female. Since the duration of an employee's interaction with supervisor due to full time and part time work arrangement could affect a supervisor's perception about an employee's performance, work arrangement (part time/full time) was introduced as a control variable. $88 \%$ of respondents were full time employees and 12\% were part time employees. The education level of an employee was introduced as control variable because it could affect his/her quality of work, and consequently could develop positive or negative perceptions about him/her in the eyes of supervisor. $56 \%$ respondents had completed 16 years of education, 24\% had completed 14 years of education, and the rest of $20 \%$ had completed 12 -year education.

\subsection{Results}

The data analysis process began with a preliminary data screening and checking for different assumptions. The detail of mean, standard deviation, and correlations between independent, dependent, and mediating variables is given in Table 1. The table demonstrates that the correlation between ingratiation and helping is positive and moderate. Similarly, the correlation between helping and supervisor satisfaction is also positive and moderate.

\begin{tabular}{|c|c|c|c|c|}
\hline & Mean & SD & HB & IB \\
\hline Helping Behavior(HB) & 3.55 & 1.062 & 1 & \\
\hline Ingratiation Behavior(IB) & 3.84 & 1.045 & $.318^{* *}$ & 1 \\
\hline Supervisor Satisfaction(SS) & 3.89 & .715 & $.317 * *$ & 0.09 \\
\hline
\end{tabular}

Table 1. Mean, Standard Deviation (SD) and Correlations

Next, convergent and discriminant validity of the scale following the recommendations of Fornell and Larker (1981) was determined. A confirmatory factor analysis was performed and factor loadings and covariance to estimate discriminant and convergent validity (Table 3) were used in an excel sheet developed by James Gaskin. The values of fit indices cmin/DF, RMR, RMSEA were below threshold 
whereas the values of baseline comparison indices were above 0.90 that demonstrated perfect fit (Table 2).

\begin{tabular}{|l|r|r|r|r|r|}
\cline { 2 - 6 } \multicolumn{1}{c|}{} & \multicolumn{1}{c|}{ CMIN/DF } & \multicolumn{1}{c|}{ RMR } & \multicolumn{1}{c|}{ CFI } & \multicolumn{1}{c|}{ TLI } & \multicolumn{1}{c|}{ RMSEA } \\
\hline Model 1: Ingratiation Behavior & 2.54 & .025 & .995 & .987 & .060 \\
\hline Model 2: Helping Behavior & 2.27 & .034 & .992 & .983 & .054 \\
\hline Model 3: Supervisor Satisfaction & 1.54 & .035 & .987 & .980 & .035 \\
\hline Model 4: Full CFA Model & 2.816 & .076 & .932 & .921 & .063 \\
\hline
\end{tabular}

Table 2. The Results of Confirmatory Factor Analysis: The Model Fit Indices

The values of the critical ratio (CR) and average variance extracted (AVE) are above or almost near to threshold values of .70 and .50 and demonstrate convergent validity of the scales. Similarly, values of MSV and ASV below AVE demonstrate adequate discriminant validity. Moreover, ratio of chi-square to degrees of freedom is less than 3 that also represents discriminant validity (Carmines \& Mclever, 1981).

\begin{tabular}{|l|r|r|r|r|}
\hline \multirow{2}{*}{ Variables } & \multicolumn{2}{|c|}{ Convergent Validity } & \multicolumn{2}{|c|}{ Discriminant Validity } \\
\cline { 2 - 5 } & \multicolumn{1}{|c|}{ CR } & \multicolumn{1}{|c|}{ AVE } & \multicolumn{1}{c|}{ MSV } & ASV \\
\hline 1) Ingratiation Behavior & 0.87 & .53 & 0.11 & 0.06 \\
\hline 2) Helping Behavior & 0.90 & 0.57 & 0.31 & 0.21 \\
\hline 3) Supervisor Satisfaction (SS) & 0.63 & 0.48 & 0.31 & 0.16 \\
\hline
\end{tabular}

Table 3. Convergent Validity and Discriminant Validity Statistics of the Measures

Following Podsakoff, MacKenzie and Podsakoff (2012) certain steps were taken to control for common method variance. Since a study completely relying on self-reported measures can be vulnerable to criticism, the data were collected from multiple sources i.e. supervisor and employee. Second, rating scale anchors used to obtain responses were different for each variable. Third, common method variance in dataset was assessed through two different tests. First, Herman single factor analysis (Podsakoff \& Organ, 1986) was performed where all items of the scale were restricted to load on a single factor. This single factor explained $22.5 \%$ variance only that is very below the threshold level (40\%) described by Podsakoff et al. (2012). Second, a CFA was performed where a common latent factor was added to full CFA model and all observed variables of this CFA model were connected with this latent factor. In this model, the paths between common latent factor and all observed variables were restricted to be equal to 1 . The loadings demonstrated that this CFA model explained 3\% to 4\% of variance in all latent factors of the study. Further, the variance in standardized regression weights of 
latent variables of this CFA model was compared with the standardized regression weights obtained from the CFA model without common latent factor. However, no significant differences were observed in the regression weights. Overall, both of the tests demonstrated that common method variance was not an issue in our study.

\subsection{Mediation Analysis}

Mediation was analyzed with the help of structural regression models in AMOS (fifth version) and performed bootstrapping as recommended by Preacher and Hayes (2004, 2008). The first structural regression model tested direct effect of ingratiation on supervisor satisfaction and did not contain mediating variable. This model demonstrated adequate fit (chi-square $=81.9 ; \mathrm{df}=51 ; \mathrm{CMIN} / \mathrm{df}=$ 1.606; RMR $=.05 ; \mathrm{CFI}=.98 ;$ RMSEA $=.03$; PClose $=.92)$. The direct effect of ingratiation on supervisor satisfaction in the absence of the mediator was significant $(\beta=.10 ; \mathrm{p}<.05)$. Hypothesis 1 was supported. Then second structural model was tested to examine the indirect effect of ingratiation on supervisor satisfaction through helping behavior. A 95\% bias-corrected confidence interval with 2000 bootstrapping samples was used. This model also demonstrated adequate fit (chi-square $=313.6$; $\mathrm{df}=141 ; \mathrm{CMIN} / \mathrm{df}=2.148 ; \mathrm{RMR}=.07 ; \mathrm{CFI}=.95 ; \mathrm{RMSEA}=.051 ;$ PClose $=.367)$. The results demonstrated support for hypothesis $2(\mathrm{H} 2)$ as the relationship of ingratiation with helping behavior was significant and positive $(\beta=.33 ; \mathrm{p}<.01)$. The results also supported hypothesis 3 stating that helping behavior is positively associated with supervisor satisfaction as the relationship of helping behavior with supervisor satisfaction was also positive and significant $(\beta=.694 ; \mathrm{p}=.01)$. The statistical support for hypotheses $\mathrm{H} 2$ and $\mathrm{H} 3$ represents that the basic conditions of mediation are satisfied (Preacher \& Hayes, 2008). Similarly, the bootstrapping estimates also demonstrated that the indirect effect of ingratiation behavior (IB) on supervisor satisfaction in presence of helping behavior was also significant ( $\mathrm{p}=.000 ; \mathrm{CI}=95 \% ; 5000$ bootstrapping samples). Thus, hypothesis $\mathrm{H} 4$ was also supported.

\begin{tabular}{|l|c|}
\cline { 2 - 2 } \multicolumn{1}{c|}{} & DV=SS \\
\hline IBàSS( Direct Effect of IB on SS without Mediator) & $.10^{*}$ \\
\hline IBàHB(Path a) & $.33^{* *}$ \\
\hline HBàSS(Path b) & $\begin{array}{c}-.19^{* *} \\
\text { Direct effect with mediator }\end{array}$ \\
\hline
\end{tabular}

**. The relationship is significant at the level .01; *. The relationship is significant at the level .05.

Table 4. Results for Mediating Role of Helping Behavior (HB) between Ingratiation Behavior (IB) and Supervisor Satisfaction (SS) 


\subsection{Moderation Analysis}

Following three conditions of moderation explained by Baron and Kenny (1986), a multiple hierarchical regression was performed to examine moderating role of ingratiation between helping behavior and supervisor satisfaction. Multicollinearity issue was resolved by standardizing independent (helping behavior), moderating (ingratiation behavior) and control variables. Control variables were entered in the first block, independent variable in the second block, moderator in third block and product term was entered in the fourth block. The results (Table 5) demonstrate that main effect of moderator is insignificant $(\beta=.034 ; \mathrm{p}>.05)$ but main effect of the independent variable $(\beta=.31 ; \mathrm{p}$ $<.01)$, and the effect of interaction term $(\beta=.105 ; \mathrm{p}<.05)$ on supervisor satisfaction are significant.

\begin{tabular}{|l|c|c|c|c|}
\cline { 2 - 5 } \multicolumn{1}{c|}{} & \multicolumn{3}{c|}{ Supervisor Satisfaction } \\
\hline Variables & Model 1 & Model 2 & Model 3 & Model 4 \\
\hline Helping Behavior (HB) & - & $.305^{* *}$ & $.304^{* *}$ & $.309^{* *}$ \\
\hline Ingratiation Behavior (IB) & - & - & $.003(.951)$ & .034 \\
\hline HB*IB & - & - & - & $.105^{*}$ \\
\hline Gender & $-.19^{* *}$ & $-.148^{* *}$ & $-.148^{* *}$ & $-.143^{* *}$ \\
Age & $-.092(.097)$ & $-.080(.133)$ & $-.080(.135)$ & $-.070(.185)$ \\
Qualification & $.011(.835)$ & $.044(.367)$ & $.044(.367)$ & $.056(.254)$ \\
Work Arrangement & $.025(.622)$ & $.011(.815)$ & $.011(.823)$ & $.003(.943)$ \\
Experience & $-.125^{*}$ & $-.121^{*}$ & $-.121^{*}$ & $-.122^{*}$ \\
Firm Size & $.048(.358)$ & $.037(.452)$ & $.037(.454)$ & $.034(.498)$ \\
\hline $\mathbf{R}^{\mathbf{2}}$ & $.058^{* *}$ & .146 & .146 & .155 \\
$\mathbf{R}^{2}$ Change & - & $.088^{* *}$ & $.000(.951)$ & $.010^{*}$ \\
\hline
\end{tabular}

**. The relationship is significant at the level .01; *. The relationship is significant at the level .05.

Table 5. Results of Regression Analysis Examining Moderating Effects of Ingratiation (IB) on Relationship of Helping (HB) and Supervisor Satisfaction (SS)

These effects were also plotted using moderation graph (Figure 2). The crossing line in plot demonstrates that positive relationship between helping behavior and supervisor satisfaction is stronger for high ingratiation and weaker for low ingratiation. In other words, low ingratiates are more affected by level of helping behavior demonstrated as compared to high ingratiates. Thus, hypothesis 5 was also supported. 


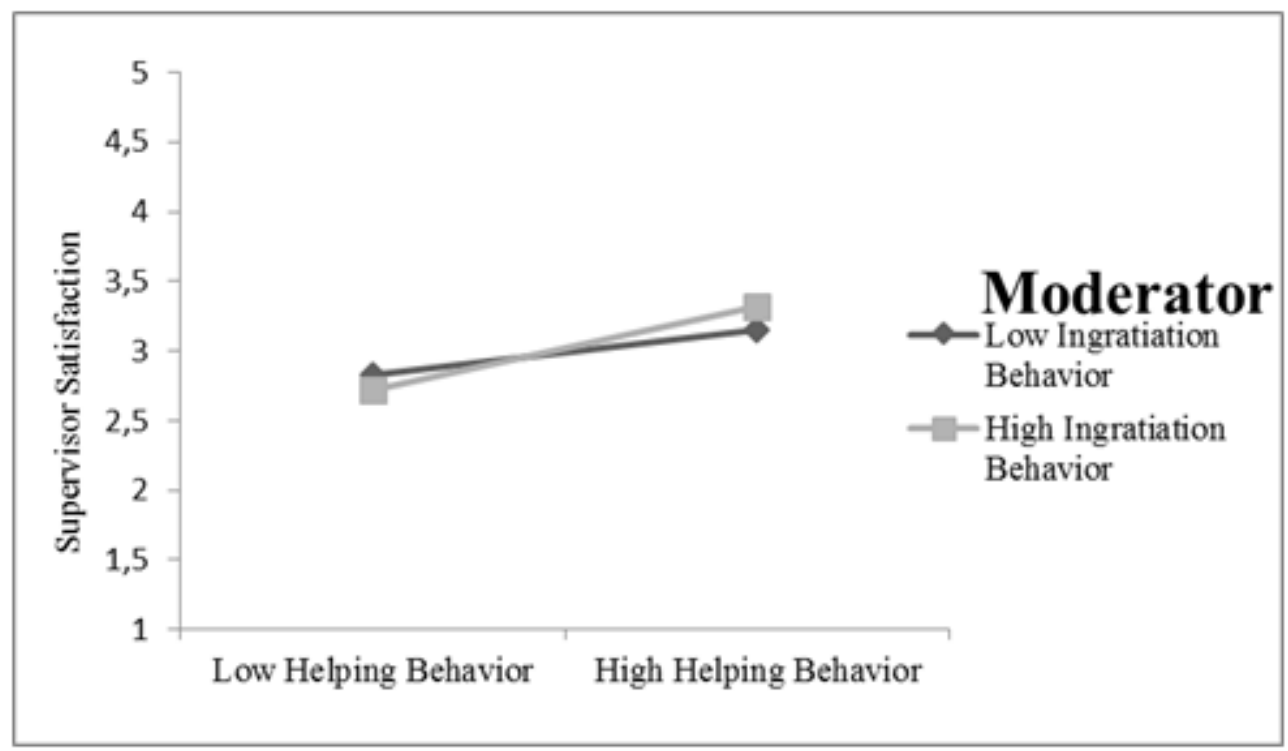

Figure 2: Moderation of Ingratiation Behavior

\subsection{Moderated Mediation Analysis}

Finally, four conditions of moderated mediation were followed (Muller, Judd \& Yzerbyt, 2005; Ng, Ang \& Chan, 2008) to test hypothesis $6 \mathrm{a}$ and $6 \mathrm{~b}$ stating that the indirect effect of ingratiation on supervisor satisfaction through helping behavior differs across high and low levels of ingratiation behavior. The first condition of moderated mediation is the significant effect of helping behavior on supervisor satisfaction (H3 of the study). Second condition is the significant interaction between helping behavior and ingratiation in predicting supervisor satisfaction (H5 of the study). Third condition is the significant effect of ingratiation on supervisor satisfaction (Model 1 in mediation analysis). Fourth condition is different indirect effects of ingratiation on supervisor satisfaction through helping behavior across high and low levels of ingratiation behavior (H6). The statistical results of first three conditions of mediation have already been discussed. The fourth condition is the most critical for establishing that the indirect effect of ingratiation on supervisor satisfaction through helping behavior differs across high and low levels of ingratiation behavior. This condition was tested according to the recommendations of Preacher, Rucker and Hayes (2007) and model 1 of moderated mediation was tested using MODMED MACRO. The indirect effects were examined at different values of ingratiation i.e. at mean value, at one standard deviation above the mean (high) and at one standard deviation below the mean (low) using 95\% confidence interval with 5000 bootstrapping samples (Selig \& Preacher, 2008). The conditional indirect effect was insignificant for employees who demonstrate 
low ingratiation (95 percent CIs between -0.0600 and 0.0724) and employees who demonstrate average ingratiation (95 percent CIs between -0.0144 and 0.0748) as the confidence intervals included zero. However, the conditional indirect effect for employees showing high level of ingratiation was significant (95 percent CIs between 0.0257 and 0.0842 ) as the confidence intervals did not include zero. Thus, hypothesis H6a and H6b were also supported.

\section{Discussion}

This research highlights the importance of supervisor-subordinate relationships in service organizations. This study contributes to the research in organizational behavior by answering question that 'when and how ingratiation could be effective?' Previous research emphasized more on customerdirected employee ingratiation but this study offers its contribution by emphasizing coworker as well as supervisor directed employee ingratiation. Moreover, this study measures effectiveness of ingratiation in terms of employee task performance representing supervisor satisfaction. There is a lack of empirical evidence on the association between ingratiation and helping behavior (H2) except for seminal work of Eastman (1994) and Nguyen et al. (2008). This is the first study that confirms a positive association between ingratiation and helping behavior. Traditionally, ingratiation is considered as an upward or supervisor-directed influence tactic (Ralston, 1985; Porter et al., 1981). The findings of this research demonstrate that ingratiation is an important tool for satisfying superiors if employees exhibit helping behaviors towards coworkers and supervisors. Particularly, new employees can benefit from ingratiation to socialize within work organizations. Moreover, existing employees can use ingratiation to establish as well as maintain better social relations with supervisors and colleagues.

This study found that ingratiation is positively and significantly associated with helping behavior. Previous research describes that supervisors appreciate employee's extra role behaviors (Van Dyne \& LePine, 1998). Helping behavior as a form of extra role behavior is also liked by supervisors (Van Dyne \& LePine, 1998), as stated earlier. The helping behavior originating from within the individual to satisfy a personal motive (Spitzmuller \& Van Dyne, 2013) is known as proactive helping behavior. Based on functional motive approach helping has also been hypothesized as a predictor of supervisor satisfaction and found statistical support in this study. These statistically significant results are in accordance with the views of Van Dyne and LePine (1998), Spitzmuller and Van Dyne (2013) and Green and Mitchell (1979)'s model of supervisory responding that helping behavior leads to supervisor satisfaction. These results encourage employees to exhibit helping behavior if they want to satisfy their supervisors. 
Statistical support for hypothesis 4 i.e. the mediating role of helping behavior between ingratiation and supervisor satisfaction answers the question that 'how ingratiation could be effective?' and supports the view that employees demonstrate job performance behaviors as a part to strengthen their self-image (Yun et al., 2007). An examination of moderating effect of ingratiation on relationship between helping behavior and supervisor satisfaction revealed that ingratiation alone does not predict supervisor satisfaction. These findings contradict propositions of Balance Theory (Heider, 1958), principle of reciprocity (Jones, 1964) as well as findings of previous studies (Gordon, 1996; Higgins, Judge \& Ferris, 2003; Judge \& Bretz, 1994; Liden \& Mitchell, 1988; Orpen, 1996; Westphal, 1998; Westphal \& Stern, 2006, 2007) reporting various positive outcomes of ingratiation like increases in compensation, recommendation for promotion. These findings discourage sole use of ingratiation at the workplace. This also represents that supervisor's value task-related performance more and ingratiation alone cannot facilitate employees to achieve personal motives until and unless they don't exhibit helping behaviors. Yet significant interaction effect of ingratiation and helping behavior on supervisor satisfaction answers 'when ingratiation could be effective?' and explains that employees exhibiting higher levels of helping behavior but not using ingratiation may be at a disadvantage in achieving supervisor satisfaction as compared to those employees demonstrating high helping as well as high ingratiation behavior. Statistical support for mediating role of helping between ingratiation and supervisor satisfaction highlights importance of helping behavior as a political skill.

The significant conditional indirect effect of ingratiation on supervisor satisfaction through helping behavior at high and low levels of ingratiation behavior provides answers for both 'when' and 'how' questions simultaneously and highlights value of ingratiation. This demonstrates that ingratiation plays a very complex role in the explaining mechanism for employees to achieve supervisor satisfaction. Particularly, positive employee behaviors pave way for success of employees' political behaviors by bridging their relationship with employee motives. This relationship remains stable at higher level of ingratiation. Thus, only the higher level of ingratiation through helping behavior can bring fruitful results for employees. This is unfortunate as such findings encourage employees to demonstrate a high level of both helping as well as ingratiation behavior to achieve their desired outcomes hence encouraging organizational politics inside organizational settings. These results can also be interpreted as dark side of organizational politics, as the employees unable to exhibit ingratiation may not benefit from their extra role performance as much as an ingratiator could. The supervisors also need to find out the motives of employee ingratiation and devise strategies accordingly as the exchange expectations may negatively affect employee attitudes towards work, like task commitment (Yukl \& Tracey, 1992). Supervisors in service organizations may find difficulty in rating employee performance and may 
develop certain skills to differentiate between employees. This is because not only competent employees but also those lacking task-related competencies may use ingratiation (Ralston, 1985).

\section{Conclusion}

The key motive of the study was to explain the mechanism through which employees can satisfy their prosocial motives (supervisor satisfaction) with social influence/impression management tactics by exhibiting organizationally desired behaviors (helping). We conclude that organizational members need to accept that ingratiation is useless without helping behavior. They also need to recognize the importance of helping behavior for achieving satisfaction of their supervisors through high level of helping behavior. However, due to the nature of ingratiation as an upward directed and soft influence strategy, organizational members also need to accept the conditional influence of ingratiation in explaining such mechanisms. Thus, we provide a thoughtful insight into how the effect of ingratiation on supervisor satisfaction may be enhanced or restrained through helping behavior within a dyadic supervisor-subordinate relationship.

\section{Limitations and Future Research}

The first limitation of this study is the cross-sectional design. Similarly, this study is not experimental in nature. Future research can focus on an experimental design by incorporating a time element and the design and analysis should be nested since this study did not use multilevel analysis. The second limitation of our study is that we have taken only two forms of ingratiation behavior, i.e. flattery and opinion conformity following Park et al. (2011). Ingratiation has been measured using the scale developed by Kumar and Beyerlein (1991) and Westphal (1998) and later used by Park et al. (2011). This scale was directed at CEOs therefore this scale was adapted in this analysis with respect to our context. We suggest researchers to consider all four dimensions of ingratiation by using some distinct scales in future research. Some tests have been performed in this research and common method bias in our dataset has not been found. However, we recommend researchers to use some alternative measure of ingratiation in future research. Third, data were collected from hotel industry in Pakistan. The nature of industry and the cultural context may affect the results therefore this study must be replicated in other sectors and other countries as well. Fourth, this study has been limited to the supervisor satisfaction while other researchers have investigated the impact of ingratiation on various employee 
outcomes (Gordon, 1996; Higgins et al., 2003; Judge \& Bretz, 1994; Liden \& Mitchell, 1988; Orpen, 1996; Westphal, 1998; Westphal \& Stern, 2006, 2007; Treadway et al., 2007). Future studies can replace supervisor satisfaction with some employee-desired outcomes. Further, as we know ingratiation is a political influence tactic (Wortman \& Linsenmier, 1977). Wu et al. (2012) reported that ingratiation leads to stress when employee is lacking political skill. Future research must investigate political skill as a possible mediator between ingratiation and employee-desired outcomes including supervisor satisfaction.

\section{References}

Appelbaum, S.H., \& Hughes, B. (1998). Ingratiation as a political tactic: effects within the organization. Management Decision, 36(2), 85-95. http://dx.doi.org/10.1108/00251749810204160

Arthur, M.B., \& Rousseau, D.M. 1996. The boundaryless career as a new employment principle. In M.G. Arthur \& D.M. Rousseau (Eds.), The boundaryless career (pp. 3-20). New York: Oxford University Press.

Ashford, S.J., \& Cummings, L.L. (1983). Feedback as an individual resource: Personal strategies of creating information. Organizational Behavior and Human Performance, 32(3), 370-398. http://dx.doi.org/10.1016/0030-5073(83)90156-3

Ashford, S.J., \& Tsui, A.S. (1991). Self-regulation for managerial effectiveness: The role of active feedback seeking. Academy of Management Journal, 34(2), 251-280. http://dx.doi.org/10.2307/256442

Baron, R.M., \& Kenny, D.A. (1986). The moderator-mediator variable distinction in social psychological research: Conceptual, strategic, and statistical considerations. Journal of Personality and Social Psychology, 51, 1173-1182. http://dx.doi.org/10.1037/0022-3514.51.6.1173

Bateman, T.S., \& Organ, D.W. (1983). Job satisfaction and the good soldier: The relationship between affect and employee citizenship. Academy of Management Journal, 26, 587-595.

http://dx.doi.org/10.2307/255908

Bauer, D.J., Preacher, K.J., \& Gil, K.M. (2006). Conceptualizing and testing random indirect effects and moderated mediation in multilevel models: New procedures and recommendations. Psychological Methods, 11, 142-163. http://dx.doi.org/10.1037/1082-989X.11.2.142 
Beehr, T.A., Glaser, K.M., Beehr, M.J., Beehr, D.E., Wallwey, D.A., Erofeev, D. et al. (2006). The nature of satisfaction with subordinates: Its predictors and importance to supervisors. Journal of Applied Social Psychology, 36, 1523-1547. http://dx.doi.org/10.1111/j.0021-9029.2006.00070.x

Bergeron, D.M. (2007). The potential paradox of organizational citizenship behavior: Good citizens at what cost?. Academy of Management Review, 32, 1078-1095. http://dx.doi.org/10.5465/AMR.2007.26585791

Blau, P. (1964). Exchange and Power in Social Life. New York: Wiley.

Bolino, M., Kacmar, K., Turnley, W., \& Gilstrap, J. (2008). A Multi-Level Review of Impression Management Motives and Behaviors. Journal of Management, 34(6), 1080-1109. http://dx.doi.org/10.1177/0149206308324325

Bolino, M., Long, D., \& Turnley, W. (2016). Impression Management in Organizations: Critical Questions, Answers, and Areas for Future Research. Annual Review of Organizational Psychology and Organizational Behavior, 3, 377-406. http://dx.doi.org/10.1146/annurev-orgpsych-041015-062337

Bolino, M.C., \& Turnley, W.H. (1999). Measuring impression management in organizations: A scale development based on the Jones and Pittman taxonomy. Organizational Research Methods, 2, 187-206. http://dx.doi.org/10.1177/109442819922005

Bolino, M.C., \& Turnley, W.H. (2005). The personal costs of citizenship behavior: the relationship between individual initiative and role overload, job stress, and work-family conflict. Journal of Applied Psychology, 90, 740-748. http://dx.doi.org/10.1037/0021-9010.90.4.740

Bowen, C.C., Swim, J.K., \& Jacobs, R. (2000). Evaluating Gender Bias on Actual Job Performance of Real People: A Meta-Analysis. Journal of Applied Social Psychology, 30, 2194-2215. http://dx.doi.org/10.1111/j.1559-1816.2000.tb02432.x

Brown, S.L., Nesse, R.M., Vinokur, A.D., \& Smith, D.M. (2003). Providing social support may be more beneficial than receiving it: Results from a prospective study of mortality. Psychological Science, 14, 320-327. http://dx.doi.org/10.1111/1467-9280.14461

Carmines, E.G., \& McIver, J.P. (1981). Analyzing Models with Unobserved Variables: Analysis of Covariance Structures. In George W. Bohrnstedt \& Edgar F. Borgatta (eds.), Social Measurement: Current Issues (pp. 65-115). Beverly Hills, CA: Sage Publications.

Castro, S., Douglas, C., Hochwarter, W., Ferris, G., \& Frink, D. (2003). The effects of positive affect and gender on the influence tactics-job performance relationship. Journal of Leadership and Organizational Studies, 10, 1-18. http://dx.doi.org/10.1177/107179190301000101 
Choi, H.J., \& Kim, Y.T. (2012). Work-family conflict, work-family facilitation, and job outcomes in the Korean hotel industry. International Journal of Contemporary Hospitality Management, 24(7), 1011-1028. http://dx.doi.org/10.1108/09596111211258892

Cook, K.S., \& Eric R.R. (2003). Social Exchange Theory. Pp. 53-76 in Handbook of Social Psychology, edited by John Delamater. New York: Kluwer Academic/Plenum Publishers.

Cooper, J., \& Fazio, R.H. (1984). A new look at dissonance theory. In L. Berkowitz (Ed.), Advances in experimental social psychology (pp. 229-262). New York: Academic Press. http://dx.doi.org/10.1016/s00652601(08)60121-5

Davidson, M.C.G., Timo, N., \& Wang, Y. (2010). How much does labor turnover cost? A case study of Australian four- and five-star hotels. International Journal of Contemporary Hospitality Management, 22(4), 451-466.

Deery, M. (2008). Talent management, work-life balance and retention strategies. International Journal of Contemporary Hospitality Management, 20(7), 792-806. http://dx.doi.org/10.1108/09596110810897619

Eastman, K.K. (1994). In the eyes of the beholder: An attributional approach to ingratiation and organizational citizenship behavior. Academy of Management Journal, 37, 1379-1391. http://dx.doi.org/10.2307/256678

Edwards, J.R. \& Lambert, L.S. (2007). Methods for integrating moderation and mediation: A general analytical framework using moderated path analysis. Psychological Methods, 12, 1-22. http://dx.doi.org/10.1037/1082-989X.12.1.1

Epstein, S. (1973). The self-concept revisited: On a theory of a theory. American Psychologist, 28, 404-416. http://dx.doi.org/10.1037/h0034679

Ferris, G.R., Frink, D.D., Beehr, T.A., \& Gilmore, D.C. (1995). Political fairness and fair politics: The conceptual integration of divergent constructs. In R.S. Cropanzano \& K.M. Kacmar (Eds.), Organizational Politics, Justice, and Support: Managing the Social Climate of the Workplace (pp. 21-36). Westport, CT: Quorum.

Ferris, G.R., Treadway, D.C., Kolodinsky, R.W., Hochwarter, W.A., Kacmar, C.J., Douglas, C. et al. (2005). Development and validation of the political skill inventory. Journal of Management, 31, 126-152. http://dx.doi.org/10.1177/0149206304271386

Festinger, L. (1957). A theory of cognitive dissonance. Evanston, IL: Row-Peterson. 
Fishbein, M., \& Ajzen, I. (1975). Belief, attitude, intention, and behavior: An introduction to theory and research. Reading, MA: Addison-Wesley.

Fornell, C., \& Larcker, D.F. (1981). Evaluating structural equation models with unobservable variables and measurement error. Journal of Marketing Research, 18, 39-50. http://dx.doi.org/10.2307/3151312

Gable, S.L., \& Haidt, J. (2005). What (and why) is positive psychology?. Review of General Psychology, 9(2), 103-110. http://dx.doi.org/10.1037/1089-2680.9.2.103

Ghalamkari, B., Mahmoodzadeh, N., Barati, N., Isah-Chikaji, A., Alkali, A.H., \& Anvari, R. (2015). The Role of HR Managers: A Conceptual Framework. Asian Social Science, 11(9), 119-124. http://dx.doi.org/10.5539/ass.v11n9p118

Glomb, T.M., Bhave, D.P., Miner, A.G., \& Wall, M. (2011). Doing good, feeling good: Examining the role of organizational citizenship behaviors in changing mood. Personnel Psychology, 61, 191-223. http://dx.doi.org/10.1111/j.1744-6570.2010.01206.x

Godfrey, D.K., Jones, E.E., \& Lord, C.G. (1986). Self-promotion is not ingratiating. Journal of Personality and Social Psychology, 50, 106-115. http://dx.doi.org/10.1037/0022-3514.50.1.106

Goffman, E. (1959). The presentation of self in everyday life. Garden City, NY: Doubleday Anchor.

Gordon, R.A. (1996). Impact of ingratiation on judgments and evaluation: A meta-analytic investigation. Journal of Personality \& Social Psychology, 71, 54-68. http://dx.doi.org/10.1037/00223514.71.1.54

Gouldner, A. (1960). The norm of reciprocity: A preliminary statement. American Sociological Review, 25, 161-178. http://dx.doi.org/10.2307/2092623

Grant, A.M., (2008). Does intrinsic motivation fuel the prosocial fire? Motivational synergy in predicting persistence, performance, and productivity. Journal of Applied Psychology, 93(1), 48-58. http://dx.doi.org/10.1037/0021-9010.93.1.48

Green, S.G., \& Mitchell, T.R. (1979). Attributional processes of leaders in leader-member interactions. Organizational Behavior and Human Performance, 23, 429-458. http://dx.doi.org/10.1016/0030-5073(79)90008-4

Gurevitch, Z.D. (1985). The receiver's dilemma: impressions formed in response to impression management. Basic Applied Social Psychology, 6, 145-157. http://dx.doi.org/10.1207/s15324834basp0602_4

Hackman, R. (1986). Who should be following whose lead? Reflections on the complex relationship between social psychology and organizational behavior. Distinguished speaker address, Academy of Management Meeting, Chicago. 
Hansen, D.M., Larson, R.W., \& Dworkin, J.B. (2003). What adolescents learn in organized youth activities: A survey of self-reported developmental experiences. Journal of Research on Adolescence, 13, 25-55. http://dx.doi.org/10.1111/1532-7795.1301006

Harris, K.J., Kacmar, M., \& Witt, L.A. (2005). An examination of the curvilinear relationship between leader-member exchange and intent to turnover. Journal of Organizational Behavior, 26 (4), 363-378. http://dx.doi.org/10.1002/job.314

Harris, K.J., Kacmar, K.M., Zivnuska, S., \& Shaw, J.D. (2007). The impact of political skill on impression management effectiveness. Journal of Applied Psychology, 92, 278-285. http://dx.doi.org/10.1037/0021-9010.92.1.278

Hayes, A.F., (2012). PROCESS: A versatile computational tool for observed variable mediation, moderation, and conditional process modeling [White paper]. Retrieved from: http://www.afhayes.com/ public/process2012.pdf

Heider, F. (1958). Psychology of Interpersonal Relations. New York: Wiley. http://dx.doi.org/10.1037/10628-000

Higgins, C.A., Judge, T.A. \& Ferris, G.R. (2003). Influence tactics and work outcomes: A meta-analysis. Journal of Organizational Behavior, 24, 89-106. http://dx.doi.org/10.1002/job.181

Holmes, J.G. (2002). Interpersonal Expectations as the building blocks of social cognition: An interdependence theory perspective. Personal Relationships, 9(1), 1-26. http://dx.doi.org/10.1111/14756811.00001

Janssen, O., \& Van Yperen, N.W. (2004). Employees' goal orientations, the quality of leader-member exchange, and the outcomes of job performance and job satisfaction. Academy of Management Journal, 47(3), 368-384. http://dx.doi.org/10.2307/20159587

Jernigan, I.E., \& Beggs, J.M. (2005). An examination of satisfaction with my supervisor and organizational commitment. Journal of Applied Social Psychology, 35(10), 2171-2192. http://dx.doi.org/10.1111/j.1559-1816.2005.tb02214.x

Johnson, D.W., \& Johnson, R.T. (2002). Cooperative learning and social interdependence theory. Theory and Research on Small Group, 4(1), 9-35. http://dx.doi.org/10.1007/0-306-47144-2_2

Johnson, B., Smith-McLallen, A., Killeya, L., \& Levin, K. (2004). Truth or consequences: Overcoming resistance to persuasion with positive thinking. In E. Knowles \& J. Linn (Eds.), Resistance and persuasion (pp. 215-233). Mahwah, NJ: Erlbaum.

Jones, E.E. (1964). Ingratiation, a Social Psychological Analysis. New York: Meredith Publishing. 
Jones, E.E., \& Pittman, T.S. (1982). Toward a general theory of strategic self-presentation. In J. Suls (Ed.), Psychological perspectives of the self (pp. 231-261). Hillsdale, NJ: Eribaum.

Jones, E.E., \& Wortman, C. (1973). Ingratiation: An attributional approach. Morristown, NJ: General Learning Press.

Judge, A.T., \& Bretz, R.D. (1994). Political influence behavior and career success. Journal of Management, 20, 43-65. http://dx.doi.org/10.1177/014920639402000103

Katz, D. (1964). Motivational basis of organizational behavior. Behavioral Science, 9, 131-146. http://dx.doi.org/10.1002/bs.3830090206

Kelley, H.H., \& Thibaut, J.F. (1978). Interpersonal relations: A theory of interdependence. New York: Wiley.

Kim, S., O'Neil, J.W., \& Cho, H. (2010). When does an emloyee not help coworkers? The efffect of leader-member exchange on employee envy and organizational citizenship behavior. International Journal of Hospitality Management, 29, 530-537. http://dx.doi.org/10.1016/j.ijhm.2009.08.003

Kolo, E. (2006). Does Automotive Service Excellence (ASE) certification enhance job performance of automotive service technicians? Ph.D. dissertation, Virginia Polytechnic Institute and State University, United States -- Virginia. Retrieved December 12, 2006, from: Dissertations \& Theses: Full Text database. (Publication No. AAT 3207969).

Kumar, K., \& Beyerlein, M. (1991). Construction and validation of an instrument for measuring ingratiatory behaviors in organizational settings. Journal of Applied Psychology, 76, 619-627. http://dx.doi.org/10.1037/0021-9010.76.5.619

Lam, W., Huang, X., \& Snape, E. (2007). Feedback-seeking behavior and leader-member exchange: Do supervisor-attributed motives matter. Academy of Management Journal, 50(2), 348-363. http://dx.doi.org/10.5465/AMJ.2007.24634440

Leary, M.R., \& Kowalski, R.M. (1990). Impression management: A literature review and twocomponent model. Psychological Bulletin, 107, 34-47. http://dx.doi.org/10.1037/0033-2909.107.1.34

LePine, J.A., \& Van Dyne, L. (1998). Predicting voice behavior in work groups. Journal of Applied Psychology, 83(6), 853-868. http://dx.doi.org/10.1037/0021-9010.83.6.853

Levy, K.N., Blatt, S.J., \& Shaver, P.R. (1998). Attachment styles and parental representations. Journal of Personality and Social Psychology, 74, 407-419. http://dx.doi.org/10.1037/0022-3514.74.2.407

Liden, R.C., \& Mitchel, T.R. (1988). Ingratiatory Behaviors in Organizational Settings. Academy of Management Review, 13(4), 572-587. 
Liden, R.C., Sparrowe, R.T., \& Wayne, S.J. (1997). Leader-Member Exchange Theory: The Past and Potential for the Future. In G.R. Ferris (Ed.), Research in Personnel and Human Resource Management (vol. 15, 47-119). Greenwich, CT: JAI Press).

Ma, E., \& Qu, H. (2011). Social exchange as motivators of hotel employees' organizational citizenship behavior: The proposition and application of a new three-diensional framework. International Journal of Hospitality Management, 30, 680-688. http://dx.doi.org/10.1016/j.ijhm.2010.12.003

Muller, D., Judd, C., \& Yzerbyt, V. (2005). When moderation is mediated and mediation is moderated. Journal of Personality and Social Psychology, 89, 852-863. http://dx.doi.org/10.1037/0022-3514.89.6.852

Ng, K., Ang, S., \& Chan, K. (2008). Personality and leader effectiveness: A moderated mediation model of leadership selfefficacy, job demands, and job autonomy. Journal of Applied Psychology, 97, 733-743. http://dx.doi.org/10.1037/0021-9010.93.4.733

Nguyen, N.T., Seers, A., \& Hartman, N.S. (2008). Putting a good face on impression management: Team citizenship and team satisfaction. Journal of Behavioral and Applied Management, 9(2), 148-168.

Organ, D.W. (1988). Organizational citizenship behavior: The "Good Soldier" syndrome. MA: Lexington Books.

Organ, D.W., \& Konovsky, M.A. (1989). Cognitive versus affective determinants of organizational citizenship behavior. Journal of Applied Psychology, 74, 157-164. http://dx.doi.org/10.1037/00219010.74.1.157

Orpen, C. (1996). Construct validation of a measure of ingratiatory behavior in organizational settings. Current Psychology, 15: 38-42. http://dx.doi.org/10.1007/BF02686932

Park, S.H., Westphal, J.D., \& Stern, I. (2011). Set up for a Fall: Insidious effects of flattery and opinion conformity towards corporate leaders. Administrative Sciences Quarterly, 56(2), 257-302. http://dx.doi.org/10.1177/0001839211429102

Parker, S.K., \& Collins, C.G. (2010). Taking stock: Integrating and differentiating multiple proactive work behaviors. Journal of Management, 36, 633-662. http://dx.doi.org/10.1177/0149206308321554

Peters, H., \& Lievens, F. (2006). Verbal and Non-verbal Impression Management Tactics in Behavior Description and Situational Interviews. International Journal of Selection and Assessment, 14(3), 206-222. http://dx.doi.org/10.1111/j.1468-2389.2006.00348.x

Podsakoff, P.M., Ahearne, M., \& MacKenzie, S.B. (1997). Organizational citizenship behavior and the quantity and quality of work group performance. Journal of Applied Psychology, 82, 262-270. http://dx.doi.org/10.1037/0021-9010.82.2.262 
Podsakoff, P.M., \& MacKenzie, S.B. (1994). Organizational citizenship behaviors and sales unit effectiveness. Journal of Marketing Research, 3(1), 351-363.

Podsakoff, P.M., MacKenzie, S.B., \& Podsakoff, N.P. (2012). Sources of method bias in social science research and recommendations on how to control it. Annual Review of Psychology, 63, 539-569. http://dx.doi.org/10.1146/annurev-psych-120710-100452

Podsakoff, N.P., Whiting, S.W., Podsakoff, P.M., \& Blume, B.D. (2009). Individual- and OrganizationalLevel Consequences of Organizational Citizenship Behaviors: A Meta-Analysis. Journal of Applied Psychology, 94(1), 122-141. http://dx.doi.org/10.1037/a0013079

Podsakoff, P.M., \& Organ, D.W. (1986). Self-reports in organizational research: problems and prospects. Journal of Management, 12, 531-544. http://dx.doi.org/10.1177/014920638601200408

Porter, L.W., Allen, R.W., \& Angle, H.L. (1981). The politics of upward influence in organizations. In B.W. Staw \& L.L. Cummings (Eds.), Research in organizational behavior (Vol. 3, pp. 109-149). Greenwich, CT: JAI Press.

Preacher, K.J. \& Hayes, A.F. (2004). SPSS and SAS procedures for estimating indirect effects in simple mediation models. Behavior Research Methods, 36, 717-731. http://dx.doi.org/10.3758/BF03206553

Preacher, K.J., Rucker, D.D., \& Hayes, A.F. (2007). Addressing moderated mediation hypotheses: Theory, methods, and prescriptions. Multivariate Behavioral Research, 42, 185-227. http://dx.doi.org/10.1080/00273170701341316

Preacher, K.J., \& Hayes, A.F. (2008). Asymptotic and resampling strategies for assessing and comparing indirect effects in simple and multiple mediator models. Business Research Methods, 40(3), 879-891. doi: 10.3758/BRM.40.3.879. http://dx.doi.org/10.3758/BRM.40.3.879

Ralston, D.A. (1985). Employee Ingratiation: The Role of Management. Academy of Management Review, 10(3), 477-487.

Rich, T.A. (2008). Becoming the boss whisperer: An examination of the relationship between employee follower behaviors and supervisor satisfaction with employee performance. Doctoral Thesis, Minneapolis, MN., Capella University, 183 p.

Rioux, S.M., \& Penner, L.A. (2001). The causes of organizational citizenship behavior: A motivational analysis. Journal of Applied Psychology, 86, 1306-1314. http://dx.doi.org/10.1037/0021-9010.86.6.1306

Selig, J.P., \& Preacher, K.J. (2008). Monte Carlo method for assessing mediation: An interactive tool for creating conficonfidence. Retrieved from: http://www.quantpsy.org/ 
Seligman, M., \& Csikszentmihalyi, M. (2000). Positive psychology: An introduction. American Psychologist, 55, 5-14. http://dx.doi.org/10.1037/0003-066X.55.1.5

Skinner, B.F. (1963). Operant Behaviour. American Psychologist, 188, 503-515. http://dx.doi.org/10.1037/h0045185

Skinner, B.F. (1971). Contingencies of Reinforcement. East Norwalk, CT: Appleton-Century-Crofts.

Smith, C.A., Organ, D.W., \& Near, J.P. (1983). Organizational citizenship behavior: Its nature and antecedents. Journal of Applied Psychology, 68, 655-663. http://dx.doi.org/10.1037/0021-9010.68.4.653

Sonnentag, S. \& Grant, A.M. (2012). Doing good at work feels good at home, but not right away: When and why perceived prosocial impact predicts positive affect. Personnel Psychology, 65, 495-530. http://dx.doi.org/10.1111/j.1744-6570.2012.01251.x

Spitzmuller, M., \& Dyne, L.V. (2013). Proactive and reactive helping: Contrasting the positive consequences of different forms of helping. Journal of Organizational Behavior, 34, 560-580. http://dx.doi.org/10.1002/job.1848

Steizel, S., \& Rimbau-Gilabert, E. (2013). Upward influence tactics through technology-mediated communication tools. Computers in Human Behaviour, 29(2), 462-472.

http://dx.doi.org/10.1016/j.chb.2012.04.024

Susskind, A.M., Kacmar, M., \& Borchgrevink, C.P. (2007). How organizational standards and coworker support improve restaurant service. Cornell Hotel and Restaurant Administration Quarterly, 48(4), 370-379. http://dx.doi.org/10.1177/0010880407300158

Tedeschi, J.T., \& Melburg, V. (1984). Impression management and influence in the organization. In S.B. Bacharach \& E.J. Lawler (Eds.), Research in the sociology of organizations (Vol. 3, pp. 31-58). Greenwich, CT: JAI Press.

Thomas K.W., \& Pondy, L.R. (1977). Towards an 'intent' model of conflict management among principal parties. Human Relations, 30(12), 1089-1102. http://dx.doi.org/10.1177/001872677703001203

Treadway, D.C, Ferris, G.R., Duke, A.B., Adams, G.L., \& Thatcher, J.B. (2007). The moderating role of subordinate political skill on supervisors' impressions of subordinate ingratiation and ratings of subordinate interpersonal facilitation. Journal of Applied Psychology, 92, 848-855.

http://dx.doi.org/10.1037/0021-9010.92.3.848 
Van Dyne, L., Cummings, L.L., \& McLean Parks, J. (1995). Extra Role Behaviors: In pursuit of construct and definitional clarity. In L.L. Cummings \& B.M. Staw (Eds.). Research in Organizational Behavior, 17, 215-285. Greenwich, CT: JAI Press.

Van Dyne, L., \& LePine, J.A. (1998). Helping and Voice Extra-Role Behaviors: Evidence of Construct and Predictive Validity. Academy of Management Journal, 41(1), 108-119. http://dx.doi.org/10.2307/256902

Van Willigen, M., (1998). Doing good, feeling better: The effect of voluntary association membership on individual well-being. Paper presented at the Annual Meeting of the American Sociological Association, August, San Francisco, CA.

Vroom, V.H. (1964). Work and Motivation. New York: Wiley.

Westphal, J.D. (1998). Board games: How CEOs adapt to increases in structural board independence from management. Administrative Science Quarterly, 43: 511-538. http://dx.doi.org/10.2307/2393674

Westphal, J.D., \& Stern, I. (2006). The other pathway to the boardroom: How interpersonal influence behavior can substitute for elite credentials and demographic majority status in gaining access to board appointments. Administrative Science Quarterly, 51, 169-204. http://dx.doi.org/10.2189/asqu.51.2.169

Westphal, J.D., \& Stern, I. (2007). Flattery will get you everywhere (especially if you are a male caucasian): How ingratiation boardroom behavior, and demographic minority status affect additional board appointments at U.S. companies. Academy of Management Journal, 50(2), 267-288.

http://dx.doi.org/10.5465/AMJ.2007.24634434

Williams, L.J., \& Anderson, S.E. (1991). Job Satisfaction and Organizational Commitment as Predictors of Organizational Citizenship and In-Role Behaviors. Journal of Management, 17(3), 601-617. http://dx.doi.org/10.1177/014920639101700305

Wortman, C.B., \& Linsenmeier, J.A.W. (1977). Interpersonal attraction and techniques of ingratiation in organizational settings. In B.M. Staw \& G.R. Salancik (Eds.), New directions in organizational behavior (pp. 133-178). Chicago: St. Clair Press.

Wu, L.-Z., Yim, F.H.-K., Kwan, H.K., \& Zhang, X. (2012). Coping with Workplace Ostracism: The Roles of Ingratiation and Political Skill in Employee Psychological Distress. Journal of Management Studies, 49(1), 178-199. http://dx.doi.org/10.1111/j.1467-6486.2011.01017.x

Wu, L.-Z., Kwan, H.K., Wei, L.-Q., \& Liu, J. (2013). Ingratiation in the Workplace: The Role of Subordinate and Supervisor Political Skill. Journal of Management Studies, 50(6), 991-1017. http://dx.doi.org/10.1111/joms.12033 
Yukl, G., \& Tracey, J.B. (1992). Consequences of influence tactics used with subordinate, peers and the boss. Journal of Applied Psychology, 77(4), 525-535. http://dx.doi.org/10.1037/0021-9010.77.4.525

Yun, S., Takeuchi, R., \& Liu, W. (2007). Employee self-enhancement motives and job performance behaviors: Investigating the moderating effects of employee role ambiguity and managerial perceptions of employee commitment. Journal of Applied Psychology, 92(3), 745-756. http://dx.doi.org/10.1037/0021-9010.92.3.745

\section{Appendix A: Confirmatory Factor Analysis (CFA) Model}

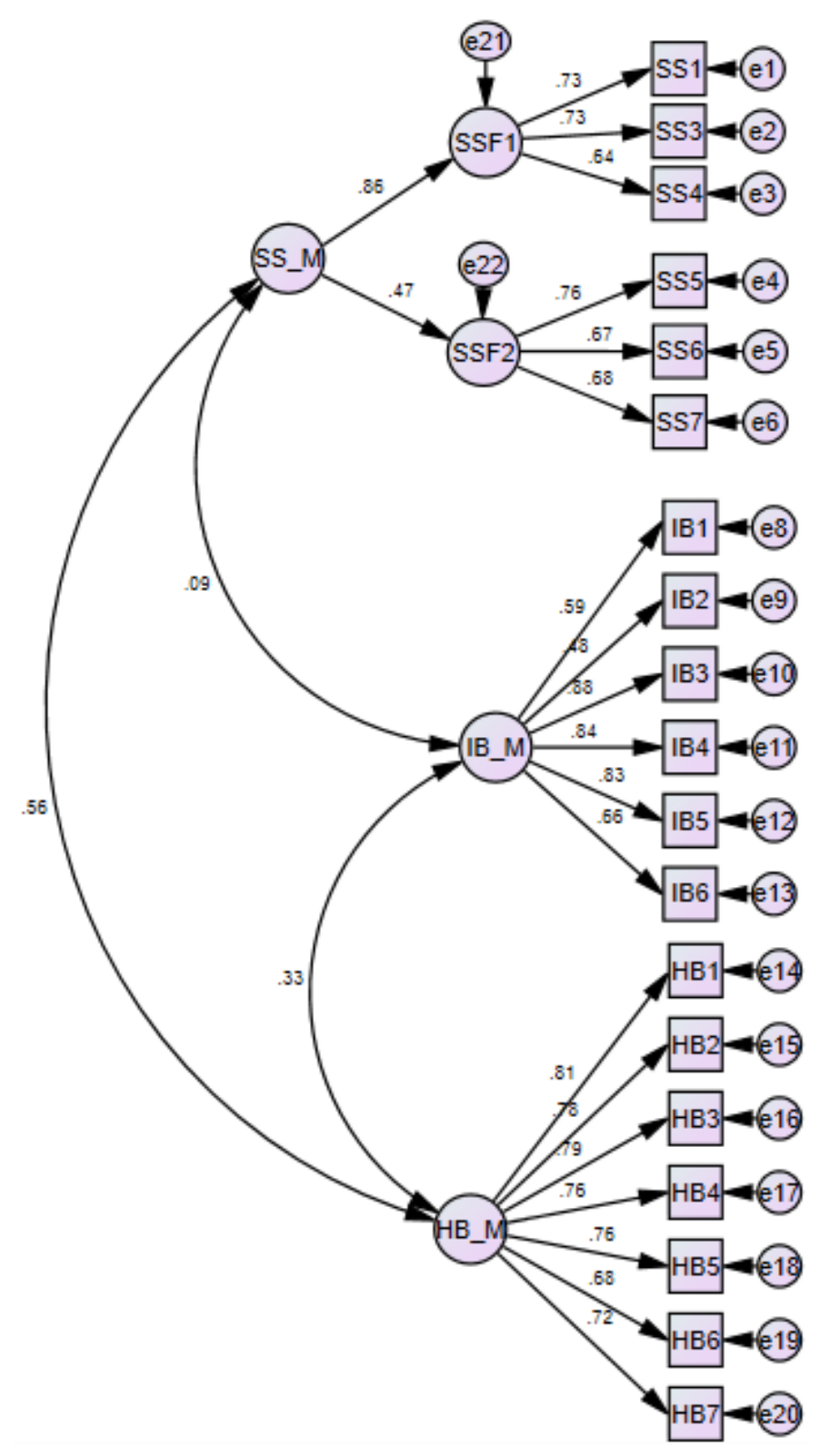




\section{Appendix B: Convergent and Discriminant Validity Estimates (A Snapshot)}

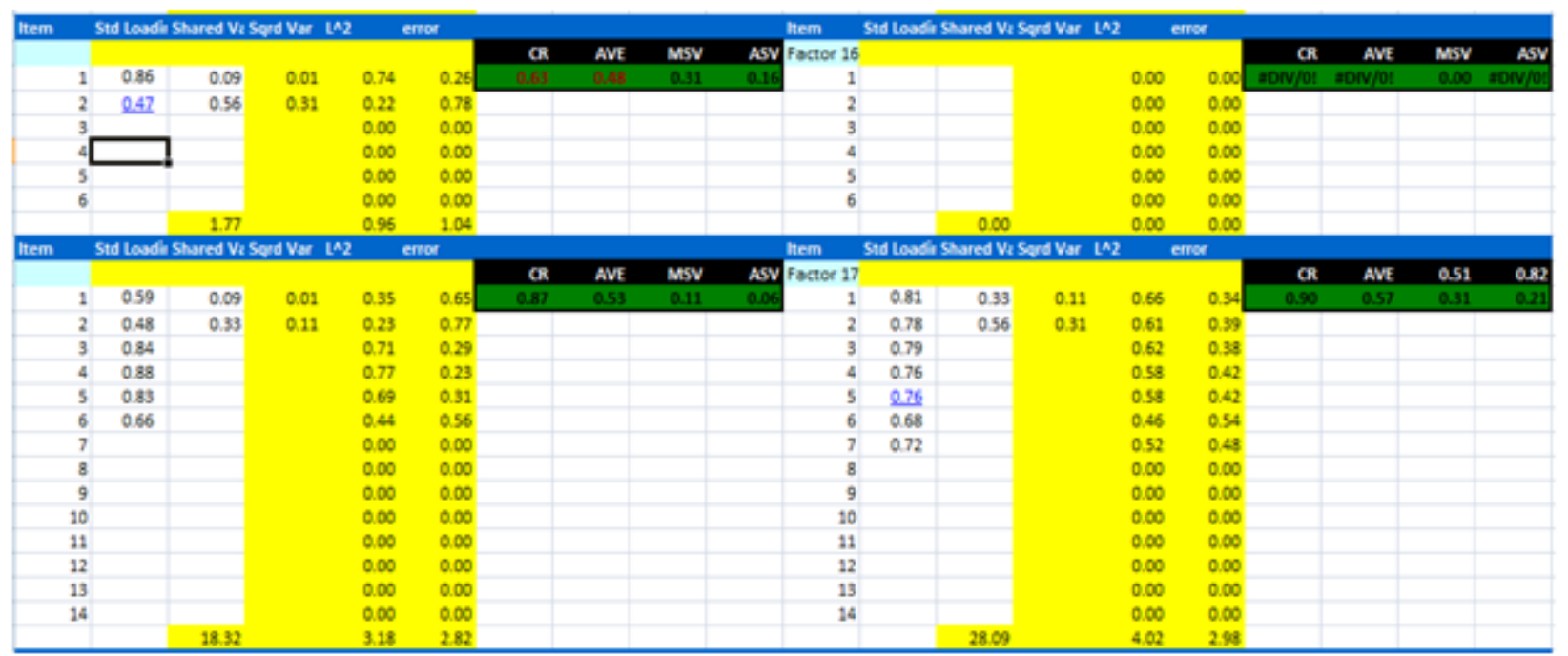

Intangible Capital, 2016 (www.intangiblecapital.org)

Article's contents are provided on an Attribution-Non Commercial 3.0 Creative commons license. Readers are allowed to copy, distribute and communicate article's contents, provided the author's and Intangible Capital's names are included. It must not be used for commercial purposes. To see the complete license contents, please visit http://creativecommons.org/licenses/by-nc/3.0/. 